\title{
Immunohistochemical Expression of the Pluripotency Factor OGT4 in Canine Mast Cell Tumours
}

\author{
T. H. M. Vargas ${ }^{*}$, L. H. Pulz ${ }^{* \dagger}$, C. N. Barra ${ }^{*}$, , S. R. Kleeb ${ }^{\ddagger}$, J. G. Xavier ${ }^{\ddagger}$, , \\ J. L. Catão-Dias ${ }^{\dagger}$, H. Fukumasu ${ }^{*}$, A. T. Nishiya and R. F. Strefezzi" \\ * Laboratório de Oncologia Comparada e Translacional, Faculdade de Zootecnia e Engenharia de Alimentos, ${ }^{\dagger}$ Faculdade de \\ Medicina Veterinária e Zootecnia, Universidade de São Paulo, ${ }^{\star}$ Universidade Metodista de São Paulo, São Bernardo do \\ Campo, ${ }^{\S}$ Universidade Paulista and ${ }^{\|}$Universidade Anhembi-Morumbi, São Paulo, Brazil
}

\begin{abstract}
Summary
Cancer stem cells (CSCs) are related to malignancy and resistance to chemotherapy in several tumours. OCT4 is a 'pluripotency factor' that is expressed by these cells. The aim of the present study was to investigate OCT4 expression in canine cutaneous mast cell tumours (MCTs) by means of immunohistochemistry. Twenty-eight cases were evaluated and showed variable immunolabelling patterns. The dogs were treated by surgery alone and followed up for a minimum of 180 days. No significant difference was found between histopathological grades and similar results were obtained for mortality due to the disease and post-surgical survival. These preliminary results suggest that OCT4 expression is not a precise prognostic indicator for canine MCT.
\end{abstract}

(C) 2015 Elsevier Ltd. All rights reserved.

Keywords: cancer stem cell; dog; mast cell tumour; OCT4 protein

Mast cell tumours (MCTs) are important neoplasms in veterinary practice, accounting for approximately $20 \%$ of canine tumours and $30 \%$ of the malignant neoplasms in this species (Bostock, 1973; Hottendorf and Nielsen, 1967; Strefezzi et al., 2003; Misdorp, 2004). MCT malignancy is evaluated based on cell differentiation levels by histopathological examination, but there is considerable variation among pathologists due to the subjective features that are analysed with the main grading systems (Patnaik et al., 1984; Kiupel et al., 2011).

Several studies have shown the importance of prognostic tools in oncology. The histopathological grading systems of Patnaik et al. (1984) and Kiupel et al. (2011) are used routinely to predict the behaviour of MCTs. However, additional prognostic markers have been shown to improve prediction.

Correspondence to: R. F. Strefezzi (e-mail: rstrefezzi@usp.br).
These include mitotic index (Romansik et al., 2007; Strefezzi et al., 2014), Ki67 expression (Abadie et al., 1999; Sakai et al., 2002; Strefezzi et al., 2010), BAX expression (Strefezzi et al., 2012), nuclear morphometry (Strefezzi et al., 2009) and the immunohistochemical patterns of KIT labelling (Zemke et al., 2002; Kiupel et al., 2004).

OCT4 is a transcription factor located in the Pit, Oct and Unc (POU) family and it is highly expressed in pluripotent cells. For this reason, it is considered to be a stem cell marker (Liedtke et al., 2008). Cancer stem cells (CSCs) are believed to initiate and maintain the neoplastic cell population. This cell population is also associated with malignancy and resistance to chemotherapy. Marfels et al. (2013) correlated higher OCT4 expression with increased resistance to chemotherapy in human patients with hepatocellular carcinomas. Similar results were obtained by Wen et al. (2013) in patients with colorectal 
cancer. Nevertheless, it was demonstrated that OCT4 immunoexpression is indicative of favourable prognosis in cases of rectal cancer after chemoradiotherapy (Saigusa et al., 2009). Raman et al. (2006) showed the absence of immunolabelling in renal carcinoma, probably related to low numbers of CSCs. Furthermore, OCT4 expression is increased in human seminomas and breast carcinomas and associated with tumour progression (Ezeh et al., 2005). High OCT4B expression is an independent prognostic tool related to good prognosis in patients with prostate cancer (Resende et al., 2013).

Webster et al. (2007) described OCT4 expression in several canine neoplasms, including MCTs, but did not compare OCT4 expression levels with clinical follow-up. OCT4 is expressed weakly by cultured canine prostate carcinoma cells (Moulay et al., 2013). Wilson et al. (2008) found OCT4 mRNA expression in canine osteosarcomas, although samples were negative for OCT4 by immunohistochemistry (IHC).

The aim of the present study was to characterize OCT4 immunohistochemical expression in canine cutaneous MCTs, in order to investigate possible associations with histological differentiation grades, mortality and post-surgical survival.

Twenty-eight cases of canine cutaneous MCTs were selected. Dogs were treated in the Veterinary Hospitals at Universidade de São Paulo, Universidade Metodista de São Paulo and Universidade Anhembi-Morumbi. After complete excision, tumour samples were processed routinely for histopathology. Sections $(4 \mu \mathrm{m})$ were stained with haematoxylin and eosin (HE) (Prophet et al., 1992) and graded, according to the methods of Patnaik et al. (1984) and Kiupel et al. (2011), by three veterinary pathologists who had no clinical information about the cases. The final histopathological grade was defined by consensus. The criteria for inclusion in the present study were: adequate amount of tissue; complete clinical follow-up (minimum 180 days); treatment by surgery with no adjuvant radiotherapy or chemotherapy. Censored data were deaths not related to the disease and dogs that were alive at the end of the follow-up.

IHC was performed in the Laboratório de Oncologia Comparada e Translacional at Faculdade de Zootecnia e Engenharia de Alimentos, Universidade de São Paulo. Sections were placed onto silane-treated slides, dewaxed in xylene for $30 \mathrm{~min}$ and rehydrated in graded alcohols and distilled water. Endogenous peroxidase was blocked by incubation of the slides in $\mathrm{H}_{2} \mathrm{O}_{2} 3 \%$ in methanol. Antigen retrieval was achieved by heating the slides at $90^{\circ} \mathrm{C}$ in citrate buffer for $25 \mathrm{~min}$ in a steamer. In order to block non-specific interactions, samples were incubated with 5\% skimmed milk for 20 min. A primary mouse polyclonal anti-OCT3/4 antibody (clone G-10, code sc5279, Santa Cruz Biotechnology, Santa Cruz, California, USA) was applied overnight at a 1 in 50 dilution. The sections were incubated with secondary antibody (Advanced HRP, code K406889-2, Dako, Carpinteria, California, USA) for 25 min. Labelling was 'visualized' with 3, 3'-diaminobenzidine and sections were counterstained with Harris' haematoxylin. For negative controls, primary antibody was replaced with normal mouse IgG under the same conditions and the positive control was a section of a human seminoma.

OCT4 labelling was classified by two observers simultaneously as nuclear and/or cytoplasmic or negative. Since OCT4 is a transcription factor, only nuclear labelling was considered positive. OCT4 positivity was compared with histopathological grades (Patnaik et al., 1984; Kiupel et al., 2011) using the ANOVA/Kruskal-Wallis and Mann-Whitney tests. Mortality due to the disease was evaluated with Fisher's exact test. Finally, survival data were analysed by the Kaplan-Meier method, followed by log-rank test. Significance was defined as $5 \%$. Data were analysed with GraphPad Prism software (Version 4.02 for Windows, GraphPad Software).

Thirty-six MCTs from 28 dogs were studied. The mean age was 9.6 years and 22 of the dogs were female $(61.2 \%)$. Crossbred dogs were the most common (10/ $28,29.1 \%$ ), followed by boxers, dachshunds, Labradors and poodles $(3 / 28,10.7 \%$ each $)$ and Brazilian fila $(2 / 28,7.1 \%)$. The remaining breeds were the American pitbull, doberman pinscher, miniature pinscher and schnauzer. Five dogs had two lesions and one dog had four lesions. In these cases, the disease was classified according to the lesion of highest grade, rendering 10 grade I, 10 grade II $(10 / 28$, $35.7 \%$ each) and eight grade III MCTs (8/28, $28.6 \%$ ) when using the three-tier system (Patnaik et al., 1984); or 18 low-grade and 10 high-grade cases, when the two-tier system was applied (Kiupel et al., 2011).

OCT4 immunolabelling varied among the samples, 21 showed cytoplasmic and nuclear labelling (Fig. 1), while in six tumours only the cytoplasm was positive (Fig. 2) and one sample was negative for OCT4. Six grade I $(6 / 10,60 \%)$, nine grade II $(9 / 10,90 \%)$ and six grade III MCTs $(6 / 8,75 \%)$ were positive for OCT4. In the two-tier system, thirteen $(13 / 18,72.2 \%)$ were positive for OCT4 among the low-grade MCTs and eight $(8 / 10,80 \%)$ among the high-grade MCTs. No significant difference was found between histopathological grades using ANOVA/Kruskal-Wallis $(P=0.3144)$ followed by 


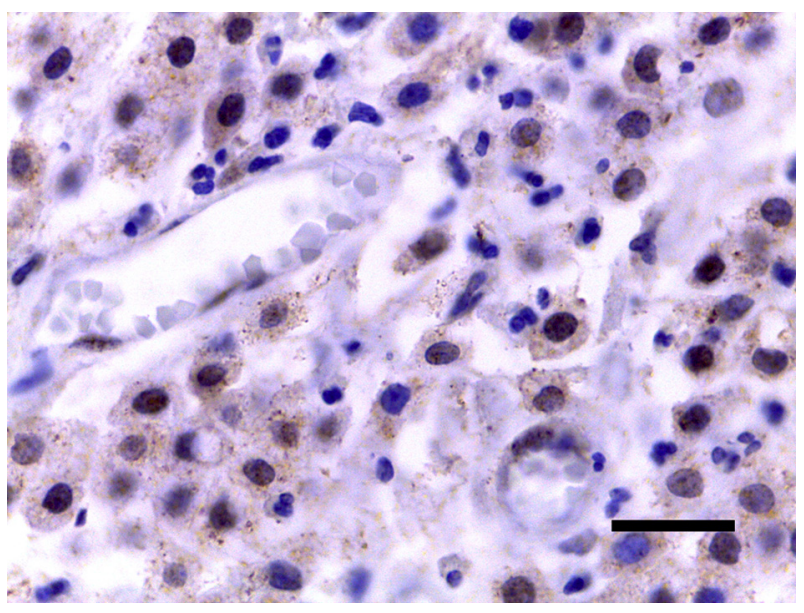

Fig. 1. Mast cell tumour showing nuclear and cytoplasmic expression of OCT4. IHC. Bar, $20 \mu \mathrm{m}$.

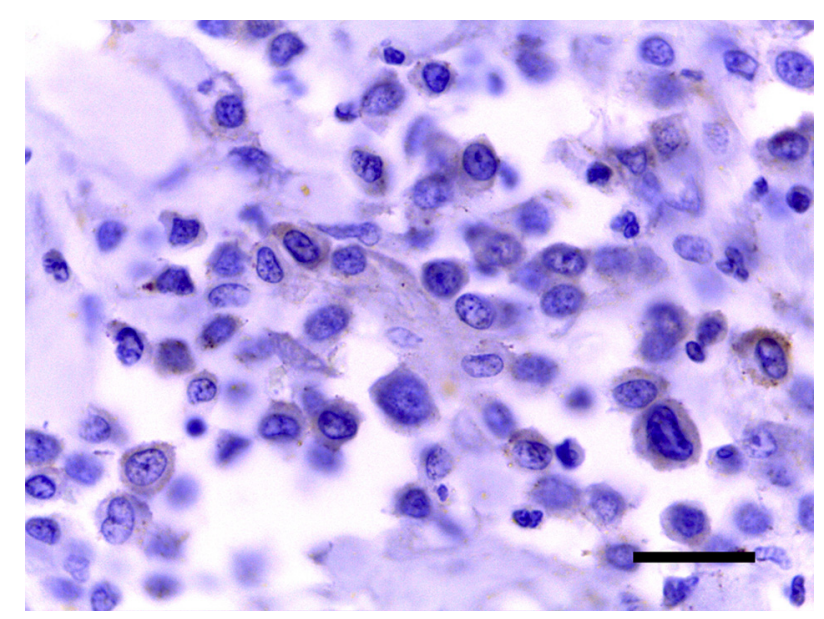

Fig. 2. Mast cell tumour showing cytoplasmic expression of OCT4, with no nuclear labelling. IHC. Bar, $20 \mu \mathrm{m}$.

Dunn's multiple comparison post-test $(P>0.05)$ and Mann-Whitney test $(P=0.7493)$. Nine of the 10 $\operatorname{dogs}(90 \%)$ that died due to the MCT and 12 of the $18(66.7 \%)$ that were censored in the survival analysis were positive for OCT4 $(P=0.3642$, Fisher's exact test, Table 1). Therefore, OCT4 expression by IHG was not a prognostic indicator for post-surgical sur-

Table 1

Distribution of the mortality rates as a function of OCT4 expression

\begin{tabular}{lrrr}
\hline & \multicolumn{2}{c}{ Mortality } & Alive at the end of the study \\
\cline { 2 - 3 } & Due to MCTs & Other cause \\
\hline OCT4 $^{+}(n=21)$ & $9(42.8 \%)$ & $3(14.4 \%)$ & $9(42.8 \%)$ \\
OCT4 $^{-}(n=7)$ & $1(14.3 \%)$ & $4(57.1 \%)$ & $2(28.6 \%)$ \\
Total $(n=28)$ & $10(35.7 \%)$ & $7(25.0 \%)$ & $11(39.3 \%)$ \\
\hline
\end{tabular}

Fisher's exact test, $P=0.3642$; sensitivity $=0.90$; specificity $=0.33$. vival (Chi-square $=1.267, P=0.2603$, median survival for OCT4-positive dogs $=751$ days; Fig. 3).

OCT4 nuclear labelling was not demonstrated in embryo samples, human primitive germ cell tumours (Lenardo et al., 1989), osteosarcomas (Levings et al., 2009), normal endometrium (Matthai et al., 2006) and thyroid glands (Thomas et al., 2006). Gidekel et al. (2003) showed abundant OCT3/4 expression in germ cell tumours, but not in lung, breast, endometrial, prostate, thyroid, skin and brain tumours. In a study with testicular tumours, all seminomas and embryonic carcinomas showed nuclear positivity (De Jong et al., 2005). Mançanares et al. (2013) identified OCT4-positive cells in the metanephros, primordial gonad and hepatic parenchyma, as well as in the yolk sac cells of bovine embryos. Pluripotency was successfully induced in canine fibroblasts by transduction of OCT4 and SOX2 transcription factors (Gonçalves et al., 2012). Tai et al. (2005) investigated OCT4 immunolabelling in 30 different normal canine tissues and found that only few scattered cells in the basal layer of the epidermis were positive, the normal location for epidermal stem cells.

In the present study, almost all MCTs had some OCT4 immunolabelling, nuclear or cytoplasmic, corroborating previous observations by Webster et al. (2007). These authors found that, among the 21 different canine tumour types investigated, the highest levels of OCT4 expression were in MCTs. OCT4 expression was investigated at the protein and mRNA levels by others, but the results were not conclusive due to the presence of pseudogenes and different isoforms of the protein (De Jong and Looijenga, 2006). Moulay et al. (2013) showed negative OCT4 expression in canine prostate carcinomas by polymerase chain reaction (PGR) and reverse

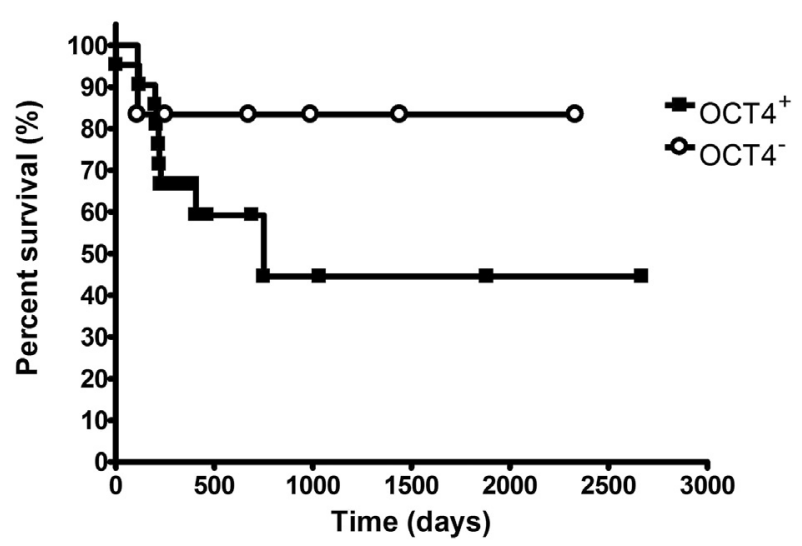

Fig. 3. Survival curves for dogs with cutaneous MCT according to OCT4 expression $(P=0.2603$, Chi-square $=1.267$, median survival for OCT4-positive dogs $=751$ days, log-rank test). Points indicate the time at which survival was censored. 
transcriptase PGR. Despite the expression of OCT4 in canine osteosarcomas, it was not labelled by IHC (Wilson et al., 2008). In canine mammary tumours, only peripheral cells of cultured spheroids and single cells were positive for OCT4 expression (Ferletta et al., 2011). Lim et al. (2012) did not find OCT4 expression in the adult canine brain.

The identical C-terminal structure of the two OCT4 isoforms increases the risk of false-positive results in protein studies (Liedtke et al., 2008). Moreover, variation in the location of OCT4 is also related to the presence of different isoforms. OCT4A, which is believed to sustain stem cell properties, is confined to the nucleus (Cauffman et al., 2006). On other hand, OCT4B shows cytoplasmic localization and is able to activate or repress the transcription of OCT4-responsive genes (Lee et al., 2006). Considering these data and in order to better compare our results, we opted to use the same antibody used by Webster et al. (2007), which does not cross-react with the OCT4B isoform and only nuclear labelling was classified as positive in the present study.

Although not statistically significant, an additional interesting result was the high mortality rate observed in the group of dogs with nuclear OCT4 expression: $90 \%$ of the dogs died due to the MCTs versus $66 \%$ in the group of censored individuals. Due to this high mortality rate in OCT4-positive dogs, we believe that complementary studies with more samples of MCTs are needed to properly evaluate the role of OCT4 in the prognosis of this neoplasm.

To the best of our knowledge, this is the first study that compared OCT4 labelling with the histological grades, disease-related mortality and post-surgical survival in veterinary oncology. In order to confirm these preliminary observations and to better understand the role of OCT4 in canine cutaneous MCTs, ongoing studies aim to evaluate the expression of different spliced isoforms and other stem cell markers.

\section{Acknowledgments}

We thank the veterinarians from the Veterinary Hospitals of Universidade de São Paulo, Universidade Metodista de São Paulo, Universidade AnhembiMorumbi and the A. C. Camargo Hospital for submitting surgical samples and Drs. V. Piana de Andrade (A.C. Camargo Hospital) and K. Ramos Moreira Leite (FM-USP) for providing control samples; Fundação de Amparo à Pesquisa do Estado de São Paulo (grant numbers 2010/05094-5 and 2013/ 13252-8) for financial support; and Conselho Nacional de Desenvolvimento Científico e Tecnológico.

\section{References}

Abadie JJ, Amardeilh MA, Delverdier ME (1999) Immunohistochemical detection of proliferating cell nuclear antigen and Ki-67 in mast cell tumors from dogs. Fournal of the American Veterinary Medical Association, 215, 1629-1634.

Bostock DE (1973) The prognosis following surgical removal of mastocytomas in dogs. Journal of Small Animal Practice, 14, 27-40.

Cauffman G, Liebaers I, Van Steirteghem A, Van de Velde H (2006) POU5F1 isoforms show different expression patterns in human embryonic stem cells and preimplantation embryos. Stem Cells, 24, 2685-2691.

De Jong J, Looijenga LH (2006) Stem cell marker OCT3/4 in tumor biology and germ cell tumor diagnostics: history and future. Critical Reviews in Oncogenesis, 12, $171-200$.

De Jong J, Stoop H, Dohle GR, Bangma CH, Kliffen M et al. (2005) Diagnostic value of OCT3/4 for preinvasive and invasive testicular germ cell tumours. Fournal of Pathology, 206, 242-249.

Ezeh UI, Turek PJ, Reijo RA, Clark AT (2005) Human embryonic stem cell genes OCT4, NANOG, STELLAR, and GDF3 are expressed in both seminomas and breast carcinoma. Cancer, 104, 2255-2265.

Ferletta M, Grawé J, Hellmén E (2011) Canine mammary tumours contain cancer stem-like cells and form spheroids with an embryonic stem cell signature. International Journal of Developmental Biology, 55, 791-799.

Gidekel S, Pizov G, Bergman Y, Pikarsky E (2003) Oct-3/4 is a dose-dependent oncogenic fate determinant. Cancer Cell, 4, 361-370.

Gonçalves NJ, Bressan FF, Souza A, Martins DS, Miglino MA et al. (2012) Canine fibroblasts expressing human transcription factors: what is in the route for the production of canine induced pluripotent stem cells. Reproduction in Domestic Animals, 47 (Suppl. 6), 84-87.

Hottendorf GH, Nielsen SW (1967) Pathologic survey of 300 extirpated canine mastocytomas. Zentralblatt fur Veterinarmedizin Reihe A, 14, 272-281.

Kiupel M, Webster JD, Bailey KL, Best S, DeLay J et al. (2011) Proposal of a 2-tier histologic grading system for canine cutaneous mast cell tumors to more accurately predict biological behavior. Veterinary Pathology, 48, 147-155.

Kiupel M, Webster JD, Kaneene JB, Miller R, Yuzbasiyan-Gurkan V (2004) The use of KIT and tryptase expression patterns as prognostic tools for canine cutaneous mast cell tumors. Veterinary Pathology, 41 , $371-377$.

Lee J, Kim HK, Rho JY, Han YM, Kim J (2006) The human OCT-4 isoforms differ in their ability to confer selfrenewal. Journal of Biological Chemistry, $\mathbf{2 8 1}$ 33554-33565.

Lenardo MJ, Staudt L, Robbins P, Kuang A, Mulligan RC et al. (1989) Repression of the IgH enhancer in teratocarcinoma cells associated with a novel octamer factor. Science, 243, 544-546. 
Levings PP, McGarry SV, Currie TP (2009) Expression of an exogenous human Oct-4 promoter identifies tumorinitiating cells in osteosarcoma. Cancer Research, 69, $5648-5655$.

Liedtke S, Stephan M, Kögler G (2008) Oct4 expression revisited: potential pitfalls for data misinterpretation in stem cell research. Journal of Biological Chemistry, 389, $845-850$

Lim JH, Koh S, Olby NJ, Piedrahita J, Mariani CL (2012) Isolation and characterization of neural progenitor cells from adult canine brains. American Gournal of Veterinary Research, 73, 1963-1968.

Mançanares CA, Leiser R, Favaron PO, Carvalho AF, Oliveira VG et al. (2013) A morphological analysis of the transition between the embryonic primitive intestine and yolk sac in bovine embryos and fetuses. Microscopy Research Technique, 76, 756-766.

Marfels C, Hoehn M, Wagner E, Günther M (2013) Characterization of in-vivo chemoresistant human hepatocellular carcinoma cells with transendothelial differentiation capacities. BioMed Central Cancer, 13, 176.

Matthai G, Horvat R, Noe M, Nagele F, Radjabi A et al. (2006) Oct-4 expression in human endometrium. Molecular Human Reproduction, 12, 7-10.

Misdorp W (2004) Mast cells and canine mast cell tumours: a review. Veterinary Quarterly, 26, 156-169.

Moulay M, Liu W, Willenbrock S, Sterenczak KA, Carlson R et al. (2013) Evaluation of stem cell marker gene expression in canine prostate carcinoma and prostate cyst-derived cell lines. Anticancer Research, 33 $5421-5432$

Patnaik AK, Ehler WJ, MacEwen EG (1984) Canine cutaneous mast cell tumor: morphologic grading and survival time in 83 dogs. Veterinary Pathology, 21, 469-474.

Prophet EB, Mills B, Arrington JB, Sobin LH (1992) Laboratory Methods in Histotechnology. Armed Forces Institute of Pathology, Washington DC, pp. 53-58.

Raman JD, Mongan NP, Liu L, Tickoo SK, Nanus DM et al. (2006) Decreased expression of the human stem cell marker, Rex-1 (zfp-42), in renal cell carcinoma. Carcinogenesis, 27, 499-507.

Resende MF, Chinen LTD, Vieira S, Jampietro J, Fonseca FP et al. (2013) Prognostication of OCT4 isoform expression in prostate cancer. Tumour Biology, 34, 2665-2673.

Romansik EM, Reilly CM, Kass PH, Moore PF, London CA (2007) Mitotic index is predictive for survival for canine cutaneous mast cell tumors. Veterinary Pathology, 44, 335-341.

Saigusa S, Tanaka K, Toiyama Y, Yokoe T, Okugawa Y et al. (2009) Correlation of CD133, OCT4, and SOX2 in rectal cancer and their association with distant recurrence after chemoradiotherapy. Annals of Surgical Oncology, 16, 3488-3498.

Sakai H, Noda A, Shirai N, Iidaka T, Yanai T et al. (2002) Proliferative activity of canine mast cell tumours evalu- ated by bromodeoxyuridine incorporation and $\mathrm{Ki}-67$ expression. Journal of Comparative Pathology, 127, 233-238.

Strefezzi RF, Kleeb SR, Xavier JG, Catão-Dias JL (2010) Avaliação da proliferação celular como indicador prognóstico para mastocitomas cutâneos caninos. Pesquisa Veterinária Brasileira, 30, 559-565.

Strefezzi RF, Kleeb SR, Xavier JG, Fukumasu H, CatãoDias JL (2012) The value of immunohistochemical expression of BAX in formulating a prognosis for canine cutaneous mast cell tumours. Fournal of Comparative Pathology, 146, 314-319.

Strefezzi RF, Xavier JG, Catão-Dias JL (2003) Morphometry of canine cutaneous mast cell tumors. Veterinary $P a$ thology, 40, 268-275.

Strefezzi RF, Xavier JG, Kleeb SR, Catão-Dias JL (2009) Nuclear morphometry in cytopathology: a prognostic indicator for canine cutaneous mast cell tumors. Fournal of Veterinary Diagnostic Investigation, 21, 821-825.

Strefezzi RF, Xavier JG, Kleeb SR, Catão-Dias JL (2014) Evaluation of histopathological grading, mitotic index and KIT labelling patterns as prognostic indicators for canine cutaneous mast cell tumours. Fournal of Comparative Pathology, 150, 113.

Tai MH, Chang CG, Olson LK, Trosko JE (2005) Oct4 expression in adult human stem cells: evidence in support of the stem cell theory of carcinogenesis. Carcinogenesis, 26, 495-502.

Thomas T, Nowka K, Lan L, Derwahl M (2006) Expression of endoderm stem cell markers: evidence for the presence of adult stem cells in human thyroid glands. Thyroid, 16, 537-544.

Webster JD, Yuzbasiyan-Gurkan V, Trosko JE, Chang CC, Kiupel M (2007) Expression of the embryonic transcription factor Oct4 in canine neoplasms: a potential marker for stem cell subpopulations in neoplasia. Veterinary Pathology, 44, 893-900.

Wen K, Fu Z, Wu X, Feng J, Chen Wet al. (2013) Oct-4 is required for an anti-apoptotic behavior of chemoresistant colorectal cancer cells enriched for cancer stem cells: effects associated with STAT3/Survivin. Cancer Letters, $333,56-65$.

Wilson H, Huelsmeyer M, Chun R, Young KM, Friedrichs K et al. (2008) Isolation and characterisation of cancer stem cells from canine osteosarcoma. Veterinary Journal, 175, 69-75.

Zemke D, Yamini B, Yuzbasiyan-Gurkan V (2002) Mutations in the juxtamembrane domain of c-KIT are associated with higher grade mast cell tumors in dogs. Veterinary Pathology, 39, 529-535.

$\left[\begin{array}{l}\text { Received, May 27th, } 2015 \\ \text { Accepted, August 31st, } 2015\end{array}\right]$ 